\title{
Ballot Box Planning: Rail Referenda Implementation
}

\author{
Kate Lowe, University of New Orleans \\ Rolf Pendall, The Urban Institute \\ Juliet Gainsborough, Bentley University \\ Mai Thi Nguyen, University of North Carolina-Chapel Hill
}

\begin{abstract}
Metropolitan areas in the United States frequently finance new rail lines with local option taxes, and, as a result, rail plans and associated taxes often come before voters as ballot measures. Existing research finds that rail ballot measures are more likely to pass when taxes are linked to specific projects and planning has broad stakeholder involvement. Such studies, however, have not examined to what extent agencies implement voter-approved projects. This research fills this gap and finds the interrelated variables of ballot measure provisions, campaign supporters and strategies, and planned rail projects contribute to varied progress toward implementation in Denver, Houston, and Miami. In addition, a fourth variable, transit agency capacity, is critical for implementation and for securing federal support. Because electoral strategies may contribute to or mitigate implementation challenges, rail and regional advocates should weigh the long-term consequences of ambitious rail plans and consider transit agency capacity.
\end{abstract}

\section{Introduction}

Local option taxes are becoming a more common tool for transportation investment (Goldman and Wachs 2003), sometimes providing funds for rail expansion. Taxes or even just rail plans may require voter approval. Research on transportation ballot measures has focused on factors associated with ballot measure passage and voter 
support (Beal, Bishop, and Marley 1996; Hannay and Wachs 2006; Peterson, Kinsey, Bartling and Baybeck 2008; Werbel and Haas 2002) or how to "win" votes. Strategies to pass transportation measures include designing them in collaboration with powerful stakeholders (Werbel and Haas 2002) and connecting new taxes to specific projects (Beal, Bishop, and Marley 1996). But, successful passage of a ballot measure is only one step in the process to actually build a rail system. Existing studies have not examined the importance of and variance in rail implementation, after the passage of ballot measures. To understand resulting transportation infrastructure, we need to understand more than what makes ballot measures more or less likely to pass. When and how does "winning" at the ballot box lead to construction of associated rail systems?

Using a comparative case study approach, this research explores to what extent voter-approved rail plans have been implemented in Denver, Houston, and Miami. None of the plans is fully implemented, but progress toward implementation varies significantly, from 48 miles under construction in Denver to 2.4 miles completed in Miami. To explain this variation, the research describes the importance of ballot measure provisions, campaign support and strategies, rail plans, and agency capacity. In these cases, plans designed to be winnable ballot measures are not fully feasible plans, although the feasibility varies, and decisions made to win votes appear to have important repercussions for implementation. Given the limited implementation of voter-approved plans, rail advocates should consider the potential political fall-out of partial implementation before advancing ambitious plans at the polls. At the same time, as the discussion of the Denver case will demonstrate, building support for a ballot measure can cement advocacy coalitions.

\section{Transportation Votes and Rail Implementation}

Infrastructure investment often relies on local options taxes. Goldman and Wachs (2003, 20, emphasis added) explain: "Local option taxes have become the levers by which communities ensure that favored but expensive projects are built." Levying such taxes may require voter approval. Studies of transportation tax ballot measures identify a range of factors that correlate with or contribute to passage; two are most relevant for this study. First, support and involvement across different sectors, including business, are associated with passage of transportation measures (Haas and Estrada 2011; Werbel and Haas 2002). The second factor is "detailed earmarking of funds in the expenditure plan" (Beal, Bishop, and Marley 2006, 74) -in other words, specific projects. Not surprisingly, voters located near planned projects were more likely to support new taxes in three elections in Sonoma County, California (Hannay and Wachs 2006) and for monorail funding in Seattle (Peterson, 
Kinsey, Bartling, and Baybeck 2008). In short, broad support, including business, and specified projects may correlate with passage of local taxes and approval of transportation infrastructure. The existing research, however, has stopped on election day, without reviewing how the design of and support for ballot measures and rail projects set the stage for rail implementation.

Even if implementation is rarely complete, there is significant variability in whether and how transit agencies may make substantial progress toward building envisioned plans. Rail systems do not appear as soon as citizens cast their votes in support, of course. Rather, implementation is a multi-year and multi-stakeholder process that faces challenges, especially cost overruns (see Flyvbjerg 2007; LavernyRaftner 2010; van Wee 2007). This research explored why three regions have disparate progress toward implementing rail plans adopted by ballot measure, thereby linking research on rail implementation and ballot measures.

\section{Case Studies}

We selected regions that exemplify where metropolitan transformation is both most challenging and possible-fast-growing southern and western metropolitan areas. The nation's fast-growing regions in the Sunbelt and Mountain West present great challenges for transformation to more sustainable urban forms, because their development patterns are typically auto-oriented. Fast growth can contribute to change, however, since growth is a critical factor for rail-associated land use change (see Giuliano 2004). Thus, understanding rail ballot measure implementation in fast-growth regions-where sustainability is possible but challenging-is especially important for researchers and policy-makers.

A comparative case study approach allows insight into complex processes (Yin 2003), and the selected cases provide varied progress toward implementation. Denver's transit agency has the most rail infrastructure in construction (48 miles). Houston's transit agency is laying down 22 miles of light-rail, but Miami's transit agency has completed the only 2.4 miles it will build out of the 89 miles of heavyrail planned. The contrasting progress occurs alongside important similarities. First, the cases share the characteristics of fast-growth regions discussed above. As Table 1 shows, the population of each metropolitan statistical area grew significantly more than the United States population between 1990 and 2000. ${ }^{1}$ Second, rail-plan votes occurred during a limited time period (2002-2004). In the following case

\footnotetext{
11990 and 2000 population totals were adjusted to 2010 MSA boundaries by totaling the population of the counties included in each 2010 MSA.
} 
study accounts, the ballot measure, associated campaign support and strategies, planned rail projects, and implementation progress are described. We then summarize the trends across the cases and conclude with implications for practice and research..

Table 1. Metropolitan Population and Growth

\begin{tabular}{|l|c|c|c|c|c|c|}
\hline & $\mathbf{1 9 9 0}$ & $\mathbf{2 0 0 0}$ & $\begin{array}{c}\text { Change } \\
\mathbf{1 9 9 0 - 2 0 0 0}\end{array}$ & $\mathbf{2 0 1 0}$ & $\begin{array}{c}\text { Change } \\
\mathbf{2 0 0 0 - 2 0 1 0}\end{array}$ & $\begin{array}{c}\text { Change } \\
\mathbf{1 9 9 0 - 2 0 1 0}\end{array}$ \\
\hline $\begin{array}{l}\text { Denver } \\
\text { MSA }\end{array}$ & $1,675,127$ & $2,196,028$ & $31 \%$ & $2,543,482$ & $16 \%$ & $52 \%$ \\
\hline $\begin{array}{l}\text { Miami } \\
\text { MSA }\end{array}$ & $4,056,100$ & $5,007,564$ & $23 \%$ & $5,564,635$ & $11 \%$ & $37 \%$ \\
\hline $\begin{array}{l}\text { Houston } \\
\text { MSA }\end{array}$ & $3,767,335$ & $4,715,407$ & $25 \%$ & $5,946,800$ & $26 \%$ & $58 \%$ \\
\hline U.S.A & $248,709,873$ & $281,421,906$ & $13 \%$ & $308,745,538$ & $10 \%$ & $24 \%$ \\
\hline
\end{tabular}

Source: U.S. Census Bureau 1990, 2000, 2010 Decennial censes

Fieldwork was part of the larger project that examines transportation investment in regions with fast population growth. Data collection was qualitative. During 2009 and 2010, we made at least two visits and conducted at least 35 semi-structured interviews in each region. Interviewees included actors from state, regional, county and local government, businesses and business associations, and community and civic organizations. Interviews were supplemented with document review, including media coverage and agency documents.

Table 2. Overview of Case Studies

\begin{tabular}{|c|l|l|l|l|l|}
\hline City & \multicolumn{1}{|c|}{$\begin{array}{c}\text { Ballot } \\
\text { Measure }\end{array}$} & $\begin{array}{c}\text { Campaign Support } \\
\text { \& Strategy }\end{array}$ & $\begin{array}{c}\text { Rail } \\
\text { Projects }\end{array}$ & $\begin{array}{c}\text { Agency } \\
\text { Capacity }\end{array}$ & Implementation \\
\hline Denver & $\begin{array}{l}0.4 \text { cent sales } \\
\text { tax }\end{array}$ & $\begin{array}{l}\text { Regional, strong } \\
\text { business role }\end{array}$ & $\begin{array}{l}122 \text { mi. light/ } \\
\text { commuter rail }\end{array}$ & High & $\begin{array}{l}48 \text { mi. under } \\
\text { construction }\end{array}$ \\
\hline Houston & $\begin{array}{l}\text { Authorized 73 } \\
\text { mi. rail, bonds } \\
\text { for only first } \\
22 \text { mi. }\end{array}$ & $\begin{array}{l}\text { Houston mayor, } \\
\text { transit agency \& } \\
\text { urban core } \\
\text { developer }\end{array}$ & $\begin{array}{l}22 \text { mi. light } \\
\text { rail financed, } \\
73 \text { approved }\end{array}$ & Moderate & $\begin{array}{l}16 \text { mi. under } \\
\text { construction }\end{array}$ \\
\hline Miami & $\begin{array}{l}0.5 \text { cent sales } \\
\text { tax }\end{array}$ & $\begin{array}{l}\text { County mayor led } \\
\text { outreach }\end{array}$ & $\begin{array}{l}89 \text { mi. heavy } \\
\text { rail }\end{array}$ & Low & $\begin{array}{l}2.4 \text { mi. } \\
\text { constructed }\end{array}$ \\
\hline
\end{tabular}




\section{Denver}

Denver's transit agency - the Regional Transit District (RTD) - is currently building 48 miles of 122 miles planned. In 2004, voters approved a 0.4 percent sales tax for the rail and transit plan. Mayors and business leaders across the region led a wellfunded campaign for this extensive regional rail system. The high-capacity transit agency has begun construction on three lines and secured over a billion dollars from the Federal Transit Administration (FTA), but full build-out would require about a billion more dollars in revenue.

Following an unsuccessful ballot measure for rail in 1997, several of the region's mayors began to work in earnest for rail and thereby lay the groundwork for the successful ballot measure campaign. Mayors across the region had formed the voluntary Metro Mayors Caucus (MMC) in the 1990s. With business elites, they established a new organization-the Transit Alliance-to educate the public and press for rail regionally. The mayors found capable and forceful partners in the private sector, not only among developers, land owners, and engineering firms that would benefit directly from transit but also among the broader business elite, who viewed livability as an important component of the metro area's national and international competitiveness.

The first success for the coalition came in 1999, when it helped win voter approval of bonds for two rail lines. Subsequently, the Colorado Department of Transportation and RTD collaborated on a combined highway-rail expansion along corridor southeast of downtown Denver.

\section{Table 3. Denver Rail Timeline}

\begin{tabular}{|l|l|}
\hline 1983 & Transit agency begins receiving sales tax revenue \\
\hline 1994 & First rail line opens \\
\hline 1997 & Ballot measure for tax increase and rail rejected at polls \\
\hline 1999 & Ballot measure approves bonds for rail and road projects \\
\hline 2004 & Voters approve 0.4\% sales tax to support expanded rail system \\
\hline 2010 & RTD enters into public-private partnership agreement for three lines \\
\hline 2012 & Groundbreaking for Northwest line (6 mi) \\
\hline 2013 & Projected opening of West Line \\
\hline
\end{tabular}

Following this success, a coalition of area mayors, the RTD board, elite and minority businesses, and organized labor crafted a ballot measure and associated rail 
plan in 2004. The measure asked voters to approve 0.4-cent sales-tax increase for a regional rail system. The transit plan, called FasTracks, reflects the regional reach of the transit agency's board and the coalition. As depicted in Figure 1, the five proposed lines stretch from the central business district to the west, northwest, north, and east and from the Tech Center toward the newly-developing Fitzsimons medical campus in Aurora. Extensions were also included on three existing lines. Oiled by a $\$ 3$ million campaign budget, the coalition overcame the opposition of the governor and a weakly-organized and poorly-funded "no" campaign to win 58 percent voter approval.

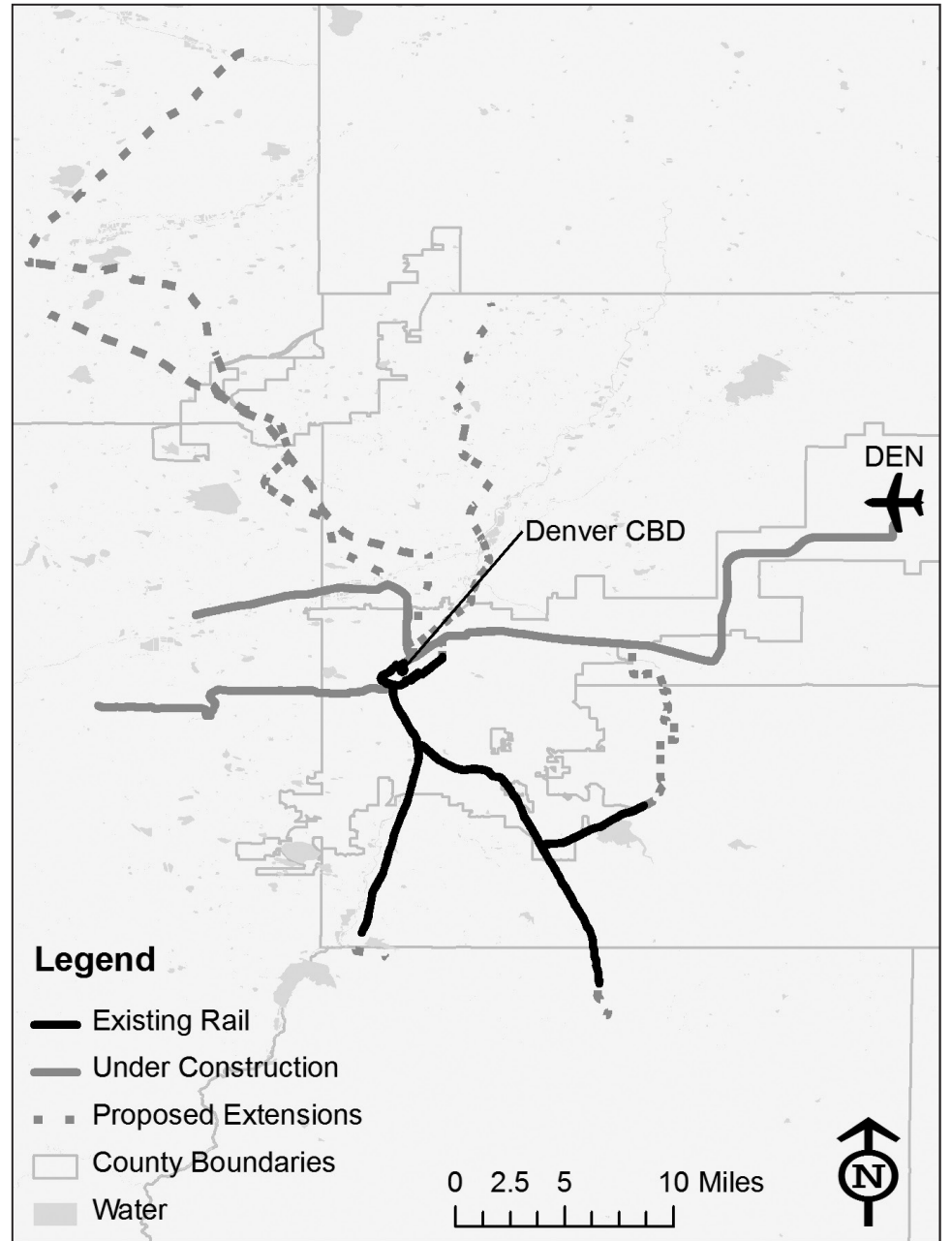

Figure 1. Denver rail system 
The Regional Transit District has substantial capacity. Since 1983, the agency has received revenue from a 0.6 percent sales tax levied within its service district. The district and board, like the FasTracks plan, are regional in scope. RTD serves eight counties and its board members are directly elected by district. By the time of the sales tax increase, the agency already operated two rail lines, which opened in 1994 and 2000 (the latter finished under budget and ahead of schedule).

As is typical, fares and other fees do not cover the full cost of service. RTD's total revenue, however, has been sufficient for a balanced budget. From 2008 to 2010, its net assets grew from $\$ 1.9$ billion to $\$ 2.2$ billion (RTD n.d.). As a total share of operating funds (22\%) and in absolute numbers ( $\$ 85.6$ million), the agency has allocated more to general administration than the two agencies profiled in the following case studies (authors' calculations from FTA 2012).

The ability of the RTD to secure federal grants has further strengthened its capacity. FTA, through a competitive program (New Starts), provided the majority of funds for RTD's two existing lines. The same competitive program will pay for significant, albeit smaller, shares for the three new lines closest to completion: the West LRT line and the Gold and East commuter rail corridors. In total, the FasTracks' budget relies on $\$ 1.3$ billion of New Starts funds. All federal funds (including New Starts awards) account for just under a quarter of the rail expansion's financial plan (RTD 2011). In addition, RTD applied to FTA's pilot public-private partnership program (Penta-P program). FTA selected the commuter rail lines as one of three pilot projects. The commuter rail lines have a design-build-operate-maintain contract, an innovative strategy that could result in cost savings for the transit agency. Although the Penta-P program has largely not succeeded in easing the process for receiving competitive federal funds (GAO 2009), RTD's application and selection show ongoing federal partnership.

Implementation is substantial, but full build-out of the system is not assured, due to cost increases and revenue shortfalls. As of early 2012, the cost estimate for full build-out was $\$ 7.8$ billion (RTD 2012), approximately 166 percent of the $\$ 4.7$ billion estimated at the time of the vote (authors' calculations based on RTD 2011, 5). Revenue has fallen short, and RTD has adjusted its sales tax projections (2005-2035) from $\$ 13.7$ to $\$ 8$ billion (RTD 2011). The Metro Mayors Caucus pledged support for a 2012 ballot measure to increase sales tax by another 0.4 percent. RTD's approved agency financial plan (RTD 2011) would allow for full build-out by 2020 (four years after original date), assuming passage of this 0.4 percent sales tax increase in 2012. The RTD board, however, later voted not to bring a sales tax increase to the ballot 
box in 2012. The dynamics are continually unfolding, and some are questioning whether remaining planned lines are the most effective rail investments for the region (Longmont Times Call 2012).

\section{Houston}

In Houston, the Metropolitan Transit Authority ("Metro") is building three lightrail lines ( 16 miles) and may construct two more. These five lines are part of a 73-mile rail system that voters approved through a 2003 ballot measure; yet, the measure gave the transit agency bonding authority only for the first five lines and avoided the potentially contentious issue of sales tax distribution. While two lines are still possible-in addition to the three under construction-civic leaders no longer seriously discuss most of the 73-mile system. Houston mayors, an urban developer, and the transit agency itself have been the major champions behind rail. Given the centralized political power in the local government and business arenas, a handful of players could negotiate what would appear in a rail ballot measure, as well as the CBD-orientation of the associated rail system.

Houston's transit agency, Metro, designed the rail expansion plan in 2003. At that time, the agency was building its first rail line, running south from downtown to the Astrodome. In April 2003, Metro released a draft plan with 41 miles of rail, but some unserved communities demanded rail investment. The agency released another plan with 55 miles of rail and then a final plan- "METRO Solutions"-with even more rail (73 miles). Metro even was explicit that rail additions were due to community requests (Perez 2003).

The rail plan faced two central challenges. Voter approval was required, because local rail foes-a long-standing presence in Houston-had successfully backed a measure that mandates voter approval for rail expansion. Second, the allocation of the Metro district sales tax would be contentious. Metro has received a 1 percent sales tax since 1978, but a more recent provision requires the agency to sub-allocate 25 percent to the service district's counties and cities. The initial plan relied on receiving the full 1 percent after 2009, when the sharing requirement was scheduled to sunset.

Elite rail-backers anticipated that municipalities and business leaders would oppose the sunset of the municipal sales tax share. Municipalities and business leaders would not want to lose the revenue that local governments were using for general mobility investments, including roadway improvements. Resistance on the tax sharing issue would mean that the rail initiative could trigger wide-spread 
opposition. Ed Wulfe, a developer and supporter of rail for the urban core, took on the task of forging a rail plan that business stakeholders would support (Williams 2003).

Then Mayor Lee Brown and Wulfe met with the Greater Houston Partnership (the area's chamber of commerce), Metro officials, and a former mayor and rail foe (Bob Lanier) to broker a measure that would appear on the ballot. Houston business leaders typically have been deeply involved in pivotal decisions for the city (Gainsborough 2003). The compromise ballot measure plan included 73 miles, but authorized bonds only for the first 22 miles, the first component to quell opposition. This phase one system is depicted in Figure 2. Second, more importantly, it extended the allocation of sales tax to municipalities, until a future unspecified referendum (that would happen in 2012). The mayor of Houston appoints the majority of members on the Metro board, and Mayor Brown successfully pressured his appointees to approve the compromise measure which then went to voters (Williams 2003). The Greater Houston Partnership endorsed the measure but did not actively campaign to support it.

Rail champions wielded significant resources, but faced opposition from U.S. Congressmen Tom DeLay and Culberson and a well-funded, anti-rail political action committee (PAC). Combined, the pro- and anti-PACs spent just under \$3 million (Wall 2003). The pro-rail campaign was primarily elite-led and targeted young voters, those who had moved from other regions, citizens concerned about urban quality of life, and minorities (Wulfe interview). Metro conducted extensive outreach and education, explaining that a yes vote would not result in more taxes. It spent about $\$ 3$ million on education (Wall 2003), but it is banned from campaigning per se. Voters narrowly approved the light-rail system of 73 miles and bonds for the first five lines.

Despite some missteps, Metro's capacity has rebounded, and the agency has secured millions of federal dollars to build rail. At the time of the METRO Solutions vote (2003), Metro appeared financially healthy and was constructing the area's first rail line without state or federal assistance. Since 1978, the agency has had dedicated revenue stream - a 1 cent sales tax (although one-quarter of that tax currently goes to municipalities as discussed above). 


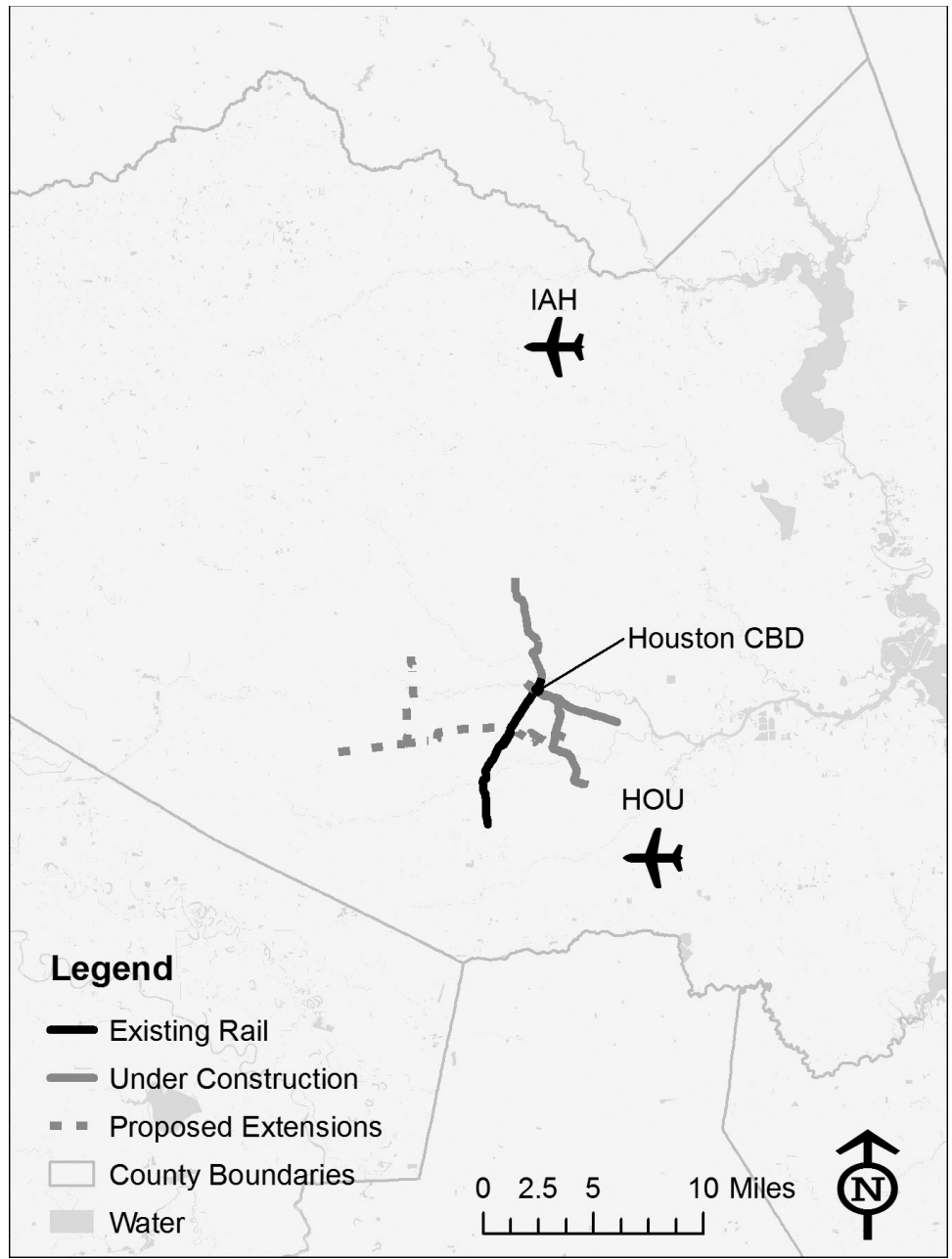

Figure 2. Houston rail system

Table 4. Houston Rail Timeline

\begin{tabular}{|c|l|}
\hline 1978 & Metro (transit agency) starts receiving one cent sales tax \\
\hline 2003 & Voters approve ballot measure for 73 miles and bond authority for 22 miles \\
\hline 2004 & First rail line opens (Red/Main Street line) \\
\hline 2011 & FTA finalizes agreement for $\$ 900$ million to support construction of two rail lines \\
\hline 2012 & Voters approve measure to continue distributing METRO tax to municipalities \\
\hline 2014 & Scheduled opening of North, East End and Southeast lines \\
\hline
\end{tabular}


The public has held somewhat negative perceptions of the agency, and Metro management has made missteps. The Houston Chronicle reported some Metro staff as suffering from "arrogant intractability," and some interviewees similarly expressed frustration with the agency's forcefulness and lack of transparency. Under the tenure of Frank Wilson, the Metro CEO who was appointed soon after the rail vote, a Metro contract for European light-rail vehicles violated the FTA's "Buy America" rules. Wilson, however, did advance a potentially cost-saving implementation model, a multi-line, design-build contract.

Furthermore, for several years following the ballot measure, Metro operated on a deficit. It borrowed to pay the share of sales tax due to the cities, thereby creating $\$ 167$ million of short-term debt. As a candidate, Mayor Parker criticized Wilson's leadership of Metro and asserted the agency had not been transparent, including on the financial prospects for implementation of some lines (Snyder 2010,). After taking office, Parker appointed new board members, who negotiated Wilson's departure in 2010. Under the subsequent CEO, Metro has responded to the FTA's Buy America concerns, increased transparency, and adopted a more cautious tone about finances and building the last two lines of the first phase. The new CEO ended the practice of borrowing to pay the funds due to cities, comparing the practice to a family living on credit cards (Snyder 2010).

Houston's Metro has secured millions in federal funds for its METRO Solutions rail plan. In November 2011, Metro and FTA signed an agreement for $\$ 900$ million that will support build-out of Houston's North and Southeast LRT lines. If the $\$ 1.4$ billion-University Line goes forward, Metro will request $\$ 700$ million for it. Like Denver's RTD, Metro was selected as one of three agencies in the FTA's pilot program for public-private partnerships.

Implementation progress is notable, but much of the rail plan has an uncertain or dubious future. Metro predicts opening the three light-rail lines under construction (16 miles) in 2014. The future for the next two lines, however, remains uncertain at best. Costs are higher than anticipated. For example, the Southeast and North corridors-just 11 miles-will cost $\$ 1.6$ billion, more than double the initial estimated costs for all 22 miles. Like Brown, subsequent mayors (Bill White and Anise Parker) control the majority of Metro's board seats and until 2012 continued to advance Metro Solution's light-rail lines. In that election cycle, voters approved (by more than three quarters) a measure that continues to divert Metro sales tax 
to local governments. The measure also prohibits use of Metro sales tax for rail expansion, until at least 2024. The new rules do allow Metro to receive up to 81 percent (up from 75\%) of the sales tax, which can still fund debt payments and bus operations. Mayor Parker and the Metro board supported the measure, explaining it would help re-balance investment between rail and bus. Critics suggested Parker and the board supported it to mute suburban opposition to rail (Rhor and Begley 2012). Thus, the future of the last two urban core lines appears uncertain at best, while the remaining rail lines (of the 73 miles approved by voters) have disappeared from debate.

\section{Miami}

In 2002, voters in Miami-Dade County approved a ballot measure that authorized a 0.5 cent sales tax for transit. The plan, which included 89 miles of heavy rail, offered investments for a wide range of constituents, but few stakeholders led its development or pushed for its passage. The county's transit agency struggles with capacity issues, but has built and opened a 2.4-mile rail spur to the airport. The rail spur is and will be the only implementation of the pledged investments, as the transit agency and metropolitan planning organization have struck the other rail investments from future plans.

The plan originated in the office of then County Mayor, Alex Penelas. His 2002 "low-key" campaign (Viglucci 2002) was likely a response to a failed 1999 sales tax initiative that citizens perceived as elite led. The county did, however, already have rail service: a 22-mile heavy rail line and a downtown monorail circulator. Penelas' office conducted broad outreach. At numerous community meetings, constituents identified the transportation investments they wanted. Community groups, however, did not lead the campaign nor deliberate together for a realistic plan.

Following outreach, the mayor's office then developed and released the "People's Transportation Plan." It had something for almost everyone-older adults, municipalities, bus riders, and the many neighborhoods slated for rail investment. The plan allocated 20 percent of the tax revenue to the county's municipalities for public works. Older adults would receive free transit passes. Miami-Dade Transit (MDT) would extend Metrorail hours and add bus routes. The combination of service improvements and decreased fare revenue alone would strain the transit agency's budget. The plan called for more: eight heavy-rail lines (89 miles) throughout the county that would add to the existing Metrorail system. Heavy rail is typically more costly than light-rail. For instance, among recently-completed projects 
that received FTA grants, the average cost of heavy rail per mile was $\$ 175$ million, and the average for light-rail was $\$ 74$ million per mile. ${ }^{2}$

This plan did not reflect that MDT had limited financial and institutional capacity. As a county agency, the bulk of MDT's operating subsidies come from Miami-Dade County. Rather than having a dedicated funding stream prior to the vote (as agencies in the other case studies did), the County Commission controls subsidies for and the budget of MDT amid an ever-changing political and fiscal environment. ${ }^{3}$

The transit agency was already operating with a deficit (\$23.9 million) at the time of the 2002 ballot measure (Lebowitz 2008). In other words, it lacked sufficient financial capacity to operate its existing services. Its financial struggles, however, were not part of the dialogue on the rail plan and sales tax increase, but have since garnered more attention. FTA identified MDT's poor, long-term fiscal capacity as reason not to award it expansion funds in $2009 .^{4}$

Implementation has been and will be minimal. There are far from sufficient funds for the service, let alone the capital, expansions in the plan. Only 2.4 miles of rail will be implemented from the 2002 transit plan. In 2004, the County Manager and the Aviation Department secured assent from the County Commission to proceed with a Metrorail spur to the airport, rather than projects prioritized in the rail plan. Using \$100 million in state funds and \$426 million from the sales tax, the transit agency built this two-mile branch from the existing Metrorail to the airport's intermodal center (Figure 3). It opened in July 2012.

In 2009, recognizing the fiscal distress of the transit agency and infeasibility of rail implementation, the Miami-Dade Board of County Commissioners voted to redirect the sales tax to the transit agency's general fund. Following this, the transit agency and metropolitan planning organization removed the other heavy rail lines from their official plans.

\footnotetext{
${ }^{2}$ Authors' calculations based on New Starts projected completed from 2003-2007 (FTA 2008). Reconstruction of lines, double-tracking, commuter rail, and bus rapid transit were not included in calculations. Completed heavy-rail $(n=3)$ and light-rail $(n=10)$ projects were included. The average is based on a small set of projects but a substantial share of U.S. rail projects completed in that period.

${ }^{3}$ In a study of a transit agency faced with similar year-to-year budgeting, Jones, Mock and Cearley $(2006,27)$ note the toll that annual budgeting demands: "CATA [Little Rock's transit provider] became engrossed in a year-to-year struggle to maintain even minimal transit services."

${ }^{4}$ Later, in November 2010, FTA suspended MDT's formula funds due to concerns about the proper use and documentation of grants, as well as potential discrepancies between recorded farebox revenue and cash on hand (Chardy 2010). In July 2011, FTA released $\$ 62.5$ million in formula funds-amid fears of emergency service cuts_-and soon thereafter $\$ 72.6$ million in stimulus funds (Brannigan, Chardy, and Haggman 2011).
} 


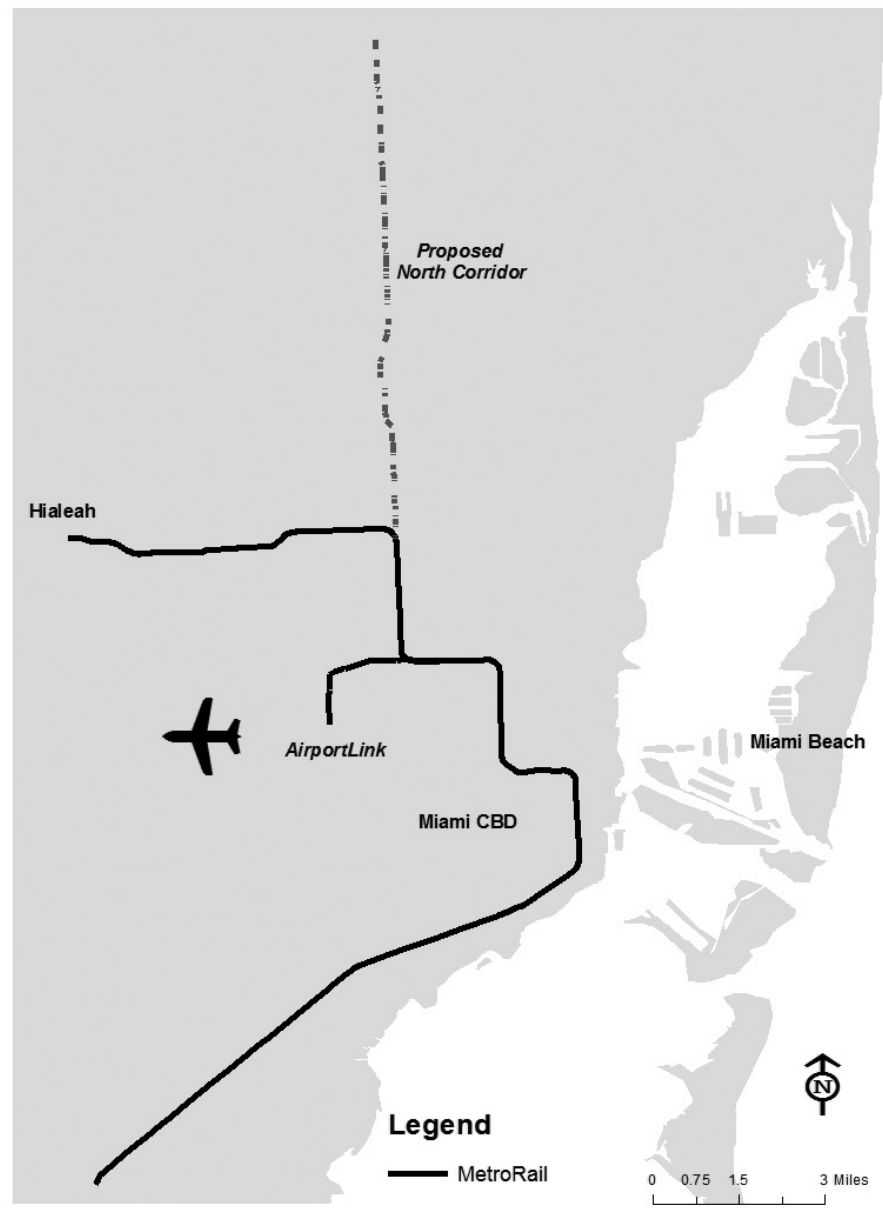

Figure 3. Miami rail system

At best, the plan was overly ambitious for a 0.5 percent sales tax, and, at worst, a "bait and switch" (Miami Herald, 2009). The plan reduced revenue and offered benefits for many county constituents, all funded by a half-cent sales tax. But, in fact, the transit agency would receive an effective rate of 0.4 cents, given the municipal allocation. While one state-level employee attributed financial woes to rising production costs, another state-level interviewee explained the plan may never have been realistic: 
Not so much the mileage, because they did have, all these transit lines had already been identified through their transitional study.... I don't think there was enough money being generated in order to do it, because heavy rail is very expensive.... I think a lot of people were pretty skeptical about the ability to deliver.

Indeed, the costs for the only rail project that will be implemented increased significantly from projected costs, from an estimated cost of $\$ 67$ million per mile in 2002 to a cost of $\$ 220$ million per mile in $2009 .{ }^{5}$

Table 5. Miami Rail Timeline

\begin{tabular}{|c|l|}
\hline 1999 & 1 cent sales tax ballot measure fails \\
\hline 2002 & Voters approve 0.5 cent sales tax for transit expansion \\
\hline 2004 & $\begin{array}{l}\text { County Commission approves construction of 2.4-mile spur from existing Metrorail } \\
\text { to airport }\end{array}$ \\
\hline 2009 & County Commission votes to move sales tax to transit agency's general fund \\
\hline 2009 & Miami-Dade MPO and MDT release plans without rail expansions \\
\hline 2012 & Miami-Dade Transit opens airport rail service \\
\hline
\end{tabular}

\section{Discussion}

The case studies demonstrate that the provisions of the ballot measure, campaign support and strategies, the rail plan, and transit agency capacity affect implementation. In the case studies, implementation progress ranges from a meager 2.4 of 89 miles of heavy rail proposed in Miami to at least 48 of 122 miles in Denver. Houston's implementation progress falls in the middle, with 16 miles under construction. Several factors identified in the literature on referenda passage-multistakeholder involvement and specified projects-may contribute to plans that include so much rail that full implementation becomes infeasible. This section first discusses the interrelated variables of ballot measure provisions, rail plans, and campaign supporters and strategy, depicted in Figure 4. Then we discuss transit agency capacity and its relationship to federal assistance.

\footnotetext{
${ }^{5}$ Authors' calculations. Costs and mileage from Lebowitz series in Miami Herald, http://www. miamiherald.com/multimedia/news/transit/index.html.
} 


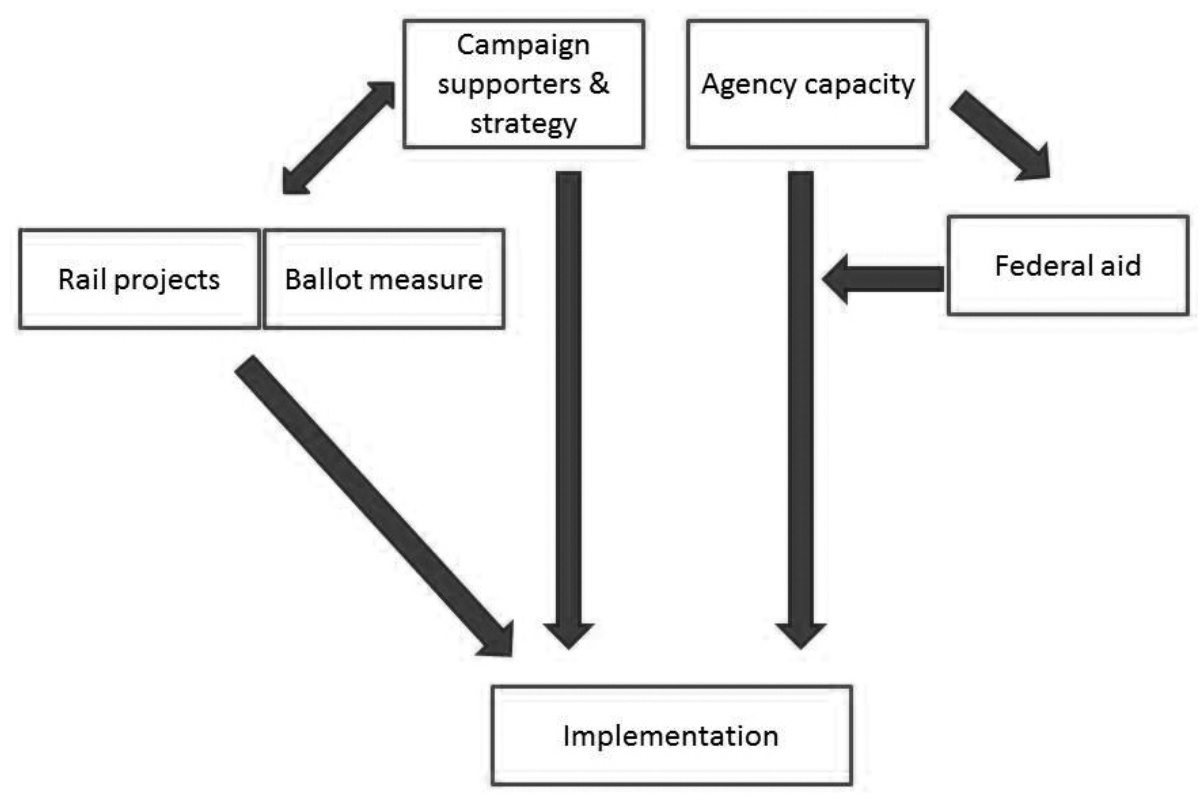

Figure 4. Implementation of ballot-box rail plans

Denver-area mayors and business elites are a powerful force behind rail. Their partnership, as well as the transit agency, reaches across the region. A regional plan reflects the geographic dispersal of key supporters. Much of the rail promised is going forward, but the full plan-with expansive extensions across the regionwould require additional revenue.

To appease communities, Houston's Metro added miles and miles to its rail plan. Meanwhile, city-based elites reduced the ballot measure's funding authorization to neutralize opposition. Thus the ballot measure reflected a dual strategy to attract votes and quell opposition. As Houston voters dominate the Metro service area and its mayor controls the majority of board seats, the plan did not need to attract regional support. Phase one lines serve the urban core. Ongoing mayoral support and Metro leadership has led to groundbreaking on three lines, but current funds and the political climate may halt further implementation.

Intense outreach resulted in a Miami-Dade People's Transportation Plan that offered something for everyone in the county. This campaign strategy, based on promises of extensive operating and capital enhancements, was especially infeasible due to the existing deficit, increased operating expenses, decreased revenue, and the especially high cost of heavy rail. The County Mayor led the outreach and 
campaign, without broad based or regional involvement. Furthermore, the ballot measure required sub-allocation of 20 percent of the revenue, further reducing funds for implementation. Only 2.4 of 89 miles will be built.

In addition to these three interrelated variables, transit agency capacity significantly affects the extent of rail implementation. The varied capacities of implementing agencies are tied to conditions that pre-date each region's rail vote. MDT-burdened by ongoing operating deficits - appears to have the least capacity. Both Denver's RTD and Houston's Metro had dedicated revenue for more than a decade prior to the ballot measures discussed. Metro has a substantial planning and outreach staff, but recently doubts about implementation of all five (phase 1) lines have surfaced. There have also been several missteps by management. RTD's capacity seems most robust, and the agency has allocated the largest amount and share of funds to general administration (authors' calculations from FTA 2012 for 2009).

Competitive federal funding can be a critical component for rail expansion, but receiving it is contingent on institutional and financial capacity, as shown in Figure 4. The award of discretionary federal funds is through a demanding application process that requires institutional planning capacity. Part of the federal process is an assessment of the long-term fiscal health of the sponsoring agency. It is precisely because of a lack of long-term fiscal capacity that FTA opted not to award expansion funds in Miami. Federal capital funds supported construction of Denver's existing lines, and FTA has issued grant agreements for $\$ 1.3$ billion to build three more. FTA awarded $\$ 900$ million for two Houstonian lines in late 2011. Thus, while FTA is powerful, it responds to existing local capacity, demonstrating the "bottomup federalism," which Altshuler and Luberoff (2004) claim characterized the midcentury era of mega-projects.

In sum, factors that emerge before a ballot measure vote appear to dramatically shape the progress toward implementation in Denver, Houston, and Miami. We suggest an interactive role between campaign support and strategies, ballot measures, and the rail plan. The latter two factors become an intervening variable for implementation, as shown in Figure 4. Likewise, Figure 4 depicts that agency capacity affects federal support which acts as an intervening variable for implementation. 


\section{Research and Policy Implications}

Rail ballot measures are critical moments for infrastructure investment and urban politics, but they represent only one moment in a complex process of planning and implementation. While these rail plans-like many-may not be fully implemented, there is significant variability in how much agencies have implemented rail plans. Reflecting both coalition make-up and political strategies to win votes, the transit capital plans and each ballot measure are highly ambitious and only partially feasible in all of our case studies. In other words, winning at the ballot box does not equate to building the proposed a rail system, but campaign-related variables and transit agency capacity contribute to varied progress toward implementation.

Coalition building — or vote attraction—strategies can build advocacy support for implementation or create political frustration. Denver's transit supporters formed and maintain a regional coalition. The continuing support, at least from some key supporters, may lead to further increases in sales tax, although not in 2012. The additional revenue would enable further implementation. The support behind Houston's rail measure was more centralized, but the continued political will of Houston mayors, along with the capacity of the transit agency, will result in three new lines. Like Denver, progress toward implementation is visible across multiple lines. Miami's plan contained benefits for all, but was not backed by a strong coalition or transit agency. While some support persists in Denver and Houston, no leaders or coalitions are pushing rail investments based on the 2002 Miami plan. The extremely limited implementation has also created such voter animosity that elected officials discuss repeal of, rather than an increase in, sales tax.

Thus, for regional coalitions and transit supporters, coalition building and transit agency capacity merit at least as much attention as passing ballot measures. The public can become more frustrated and transit funds more difficult to secure following implementation failure, as in Miami. There the transit agency's failure to implement a promised rail system led to frustration and a proposal to repeal the associated tax. The major newspaper called the commission's vote to redirect the associated sales tax the "final betrayal" related to the People's Transportation Plan. Despite continued support by major actors, suburban municipalities northwest of downtown Denver hired their own consultant and one local mayor explained her frustration and a potential desire to leave the transit district:

This area has been ignored, this entire area from about I-70 north, we rarely get transportation dollars. We will fight, and have stood together, we are standing together. This was sold as a system [FasTracks], and if 
they don't [do] it [build the Northwest line], then undo it so it releases our citizens from paying for stuff in their areas. We can make an RTA and build our own.

Given the challenges of implementation, some political fall-out may be inevitable. But, policy makers and rail advocates should consider capacity for implementation, more permanent coalition building, and the consequences of partial implementation.

Because rail investment depends on transit agencies with institutional capacity and adequate operating funds, local and federal actors could adopt tools to strengthen transit agencies. FTA logically wants to fund projects that an agency can operate fully and without starving existing services of resources. This strategy, however, has the effect of strengthening the systems that already have capacity or do not shoulder the cost of older infrastructure. With aging infrastructure and an operating deficit, MDT was ill-equipped to expand as the campaign promised.

Additional research is also needed on the governance processes that occur after plan adoption or votes. In addition to potential political fall-out, infeasible ballot measure plans blur the site of actual decision making. Because implementation is typically partial, decisions about the sequence of projects may have important distributional or environmental consequences. Ballot measures-or other citizen inputs - may provide a veneer of planning democracy, but the actual critical decision sites are scattered across time and space during implementation.

\section{References}

Alpert, Lenore, Juliet F. Gainsborough, and Allan Wallis. 2006. Building the capacity to act regionally: Formation of the Regional Transportation Authority in South Florida. Urban Affairs Review 42(2): 143-168.

Altshuler, Alan A., and David E. Luberoff. 2003. Mega-projects: The Changing Politics of Urban Public Investment. Washington, DC.: Brookings Institution Press.

Beale, Henry B. R., Elbert R. Bishop, and William G. Marley. 1996. How to pass local option taxes to finance transportation projects. Transportation Research Record 1558: 74-82.

Brannigan, Martha, Alfonso Chardy, and Matthew Haggman. 2011. Feds release more money to beleaguered Miami-Dade Transit Agency. The Miami Herald, July 15 . 
Chardy, Alfonso. 2010. Miami-Dade Transit: Federal agency suspends payments to Miami-Dade Transit. The Miami Herald, November 24.

Cohen-Blankshtain, Galit, and Eran Feitelson. 2011. Light rail routing: Do goals matter? Transportation 38(2): 343-361.

Federal Transit Administration (FTA), Office of Planning and Environment, with support from Vanasse Hangen Brustlin, Inc. 2008. Predicted and actual impacts of New Starts projects 2007: Capital cost and ridership. Washington, DC: United States Department of Transportation.

Federal Transit Administration. 2012. National Transit Database, Historical Data Files. Last modified March 6. http://www.ntdprogram.gov/ntdprogram/data. htm.

Flyvbjerg, Bent, Mette K. Skamris Holm, and Soren L. Buhl. 2003. How common and how large are cost overruns in transport infrastructure projects? Transport Reviews 23(1): 71-88.

Flyvbjerg, Bent. 2007. Policy and planning for large-infrastructure projects: Problems, causes, cures. Environment and Planning B: Planning and Design 34(4): 578-597.

Giuliano, G. 2004. Land use impacts of transportation investments. In The Geography of Urban Transportation (GUT), Third Edition, Susan Hanson and Genevieve Giuliano, Eds. New York: The Guilford Press, 237-273.

Goldman, Todd, and Martin Wachs. 2003. A quiet revolution in transportation finance: The rise of local option transportation taxes. Transportation Quarterly 57(1): 19-32.

Goldman, Todd. 2007. Transportation tax ballot initiatives as regional planning processes. Transportation Research Record 1997(1): 9-16.

Haggman, Matthew. 2009. Dade commissioners reject transit-tax repeal effort. The Miami Herald, May 6.

Hannay, Robert, and Martin Wachs. 2006. Factors influencing support for local transportation sales tax measures. Transportation 34(1): 17-35.

Jones, Kim A., Robert C. Mock, Jr., and Sarah T. Cearley. 2006. Report from an interdisciplinary case study on a public transit system in crisis. Journal of Public Transportation 9(4): 23-33. 
Laverny-Rafter, David. 2010. Federally-mandated evaluation of new starts transit projects. Journal of Public Transportation 13(3): 65-77.

Lebowitz, Larry. 2008. Transit tax fails to fulfill its lofty promise. The Miami Herald, June 8.

Longmont Times-Call. 2012. North Metro line idea is worth study. August 22.

Miami Herald. 2009. The final betrayal on the transit tax-our opinion (editorial). March 5.

Perez, D. 2003. East End may see light rail. The Houston Chronicle, July 24.

Peterson, Anne F., Barbara S. Kinsey, Hugh Bartling, and Brady Baybeck. 2008. Bringing the spatial in: The Case of the 2002 Seattle Monorail referendum. Urban Affairs Review 43(3): 403-429.

Pickrell, Don H. 1992. A desire named streetcar: Fantasy and fact in rail transit planning. Journal of the American Planning Association 58(2): 158-176.

Rhodes, Roderick A.W. 2007. Understanding governance: Ten years on. Organization Studies 28(8): 1243-1264.

Rhor, Monica, and Dug Begley. 2012. Election 2012; Metro referendum; Voters extend sharing of taxes for transit, roads. The Houston Chronicle, November 7, B3.

Regional Transit District (RTD). 2012. Annual Program Evaluation. Presentation to Board, January 17. Available at http://www.rtd-fastracks.com/media/uploads/ main/Board_Pres_1_17_12_FINAL.pdf

Regional Transit District (RTD). 2011. RTD Annual Report to DRCOG on FasTracks. Denver, CO, May.

Regional Transit District (RTD). No date. Connecting communities: Report to the region 2010/2011. Denver, CO, May.

Saucier, Heather. 2003. Smooth ride for Metro on northside: Plan finds favor with black, Hispanic voters. The Houston Chronicle, November 13.

Snyder, Mike. 2010. Metro rail-line contract may jump $\$ 100$ million. The Houston Chronicle, January 22.

Snyder, Mike. 2010. Metro rolls out budget overhaul. The Houston Chronicle, September 14. 
Stone, Clarence N. 1989. Regime Politics: Governing Atlanta, 1946-1988. Lawrence, KS: University Press of Kansas.

Taylor, Brian D., Eugene J. Kim, and John E. Gahbauer. 2009. The thin red line: A case study of political influence on transportation planning practice. Journal of Planning Education and Research 29(2): 173-193.

U.S. Census Bureau. 1990 Census of Population: General Population Characteristics (CP-1). 1990 United States Census. http://www.census.gov/prod/cen1990/cp1/ cp-1.html

U.S. Census Bureau. Profile of General Demographic Characteristics: 2000 Summary File 1. 2000 United States Census. Table DP-1.

U.S. Census Bureau. Profile of General Population and Housing Characteristics: 2010 Summary File 1. 2010 United States Census. Table DP-1.

United States Government Accountability Office (GAO). 2009. Public transportation: Federal project approval process remains a barrier to greater private sector role and DOT could enhance efforts to assist project sponsors. Report to Congressional Committees, Washington, DC., October 29.

van Wee, Bert. 2007. Large infrastructure projects: A review of the quality of demand forecasts and cost estimations. Environment and Planning B: Planning and Design 34(4): 611-625.

Viglucci, Andres. 2002. Low-key campaign pursues transit tax. The Miami Herald, October 17.

Wall, Lucas. 2003. 2003 Election; White heads into runoff, full speed ahead for rail, Metro plan on track for victory, early returns shows. The Houston Chronicle, November 5 .

Wall, Lucas, and Rad Sallee. 2003. Metro maps future of transit: 22-year plan likely to include light rail to airports, Galleria. The Houston Chronicle, April 20.

Werbel, Richard A., and Peter J. Haas. 2002. Voting outcomes of local tax ballot measures with a substantial rail transit component: Case study of effects of transportation packages. Transportation Research Record 1799(1): 10-17.

Williams, John. 2003. Rail compromise delays tough call. The Houston Chronicle, August 25. 
Williams, John. 2003. Wulfe's new goal: Striking a rail deal. The Houston Chronicle, May 26.

Yin, Robert K. 2003. Case Study Research: Design and Methods, Third Edition. Thousand Oaks, CA: Sage Publications.

\section{About the Authors}

KATE Lowe (Kate.Lowe@uno.edu) is an Assistant Professor in Planning and Urban Studies at the University of New Orleans. During her doctoral studies, she received funding through the Dwight D. Eisenhower Graduate Fellowship program and the Clarence Stein Institute. She received her Ph.D. from Cornell University in 2011. Her research focuses on the role of transportation policy on institutions, transit investment, and equitable accessibility. As part of the University New Orleans Transportation Institute, she is currently studying low-income worker accessibility in Post-Katrina New Orleans.

Rolf Pendall (rpendall@urban.org) is the Director of the Urban Institute's Metropolitan Housing and Communities Policy Center, where he leads a team of more than 40 experts on a broad array of housing, community development, and economic development topics. His research expertise includes federal, state, and local affordable housing policy and programs; land-use planning and regulation; metropolitan growth patterns; and racial residential segregation and the concentration of poverty. He currently leads the Institute's evaluation of the HUD Choice Neighborhoods demonstration and a HUD-funded research study on the transportation needs of housing choice voucher users. Between 1998 and mid-2010, he was a professor in the Department of City and Regional Planning at Cornell University. He holds a Ph.D. in City and Regional Planning from the University of California at Berkeley.

JULIET F. GAINSBOROUGH (jgainsborough@bentley.edu) is currently the Associate Dean of Arts and Sciences and an Associate Professor of Political Science at Bentley University in Waltham, Massachusetts. Her research interests include urban and regional politics, suburban political behavior, and the politics of social policy. She is the author of two books, Fenced Off: The Suburbanization of American Politics (Georgetown University Press, 2001) and Scandalous Politics: Child Welfare Policy in the States (Georgetown University Press, 2010). Her research has also appeared in such journals as the Urban Affairs Review, Policy Studies Journal, Journal of Urban Affairs, and American Politics Research. 
Dr. MAI Thi Nguyen (nguyen@unc.edu) is an Assistant Professor in the Department of City \& Regional Planning at the University of North Carolina at Chapel Hill. She is primarily interested in how planning decisions and public policy affect social and spatial inequality. Her areas of research include affordable housing policy, transportation policy, local immigration policy, and planning for socially vulnerable populations. Her work has been published in Housing Policy Debate, Housing, Theory and Society, Journal of Urban Affairs, Journal of Planning, Education and Research, Urban Studies, and the Journal of Planning Literature. She has received funding from the National Science Foundation, the Department of Housing and Urban Development, and the John D. and Catherine T. MacArthur Foundation. 